\title{
Peningkatan Keterampilan Berpikir Kritis Siswa Melalui Penerapan Model Generative Learning pada Materi Hukum Newton
}

\author{
Haris Rosdianto \\ Sekolah Tinggi Keguruan dan IImu Pendidikan (STKIP) Singkawang \\ JI. STKIP, Kel. Naram, Singkawang, Kalimantan Barat, Indonesia - 79251 \\ E-mail: harisrosdianto@yahoo.com
}

\begin{abstract}
Abstrak
Penelitian ini bertujuan untuk mendeskripsikan peningkatan keterampilan berpikir kritis siswa pada materi hukum Newton setelah diterapkan model generative learning. Jenis penelitian ini adalah penelitian pre-eksprimental dengan rancangan One Group Pretest-Posttest Design. Populasi penelitian ini adalah seluruh siswa kelas VIII MTs Makarim Al-akhlak Kota Singkawang. Teknik sampling yang digunakan adalah sampling jenuh. Instrumen penelitian yang digunakan berupa tes uraian. Data yang diperoleh tidak terdistribusi normal, sehingga data dianalisis dengan menggunakan uji statistik non parametrik yaitu Uji Mc Nemar. Dari hasil perhitungan diperoleh nilai $X^{2}$ hitung $>X^{2}$ tabel yaitu $6,125>3,841$, maka $\mathrm{H}_{0}$ ditolak dan $\mathrm{H}_{a}$ diterima pada taraf signifikansi $\alpha=0,05$. Sehingga dapat disimpulkan bahwa terjadi peningkatan keterampilan berpikir kritis siswa pada materi hukum Newton setelah diterapkan model generative learning.
\end{abstract}

Kata kunci: Generative Learning, Keterampilan Berpikir Kritis, Hukum Newton, Uji Mc Nemar.

\begin{abstract}
This study aimed to describe the improvement of students' critical thinking skills in Newton's Law subject after generative learning model was implemented. The type of this research was pre-experimental research with One Group Pretest-Posttest Design. The population of this study was all eighth grade students of MTs Makarim Alakhlak, Singkawang City. The sampling technique used was saturated sampling. The research instrument used was a description test. The data obtained was not normally distributed, so the data was analyzed using nonparametric statistical test namely Mc Nemar Test. From the calculation results, it was obtained the value of $X^{2}$ obs. $>X^{2}$ c.v. or $6.125>3.841$, then $H_{0}$ was rejected and $\mathrm{Ha}$ was accepted at the significance level $\alpha=0.05$. Therefore, it could be concluded that there was an improvement in students' critical thinking skills in Newton's law subject after generative learning model was implemeted.
\end{abstract}

Keywords: Generative Learning, Critical Thinking Skills, Newton's Law, Mc Nemar Test.

\section{PENDAHULUAN}

Fisika dianggap sebagai pelajaran yang sulit untuk dipelajari oleh siswa tingkat SMP di antara pelajaran IPA lainnya, siswa dituntut untuk memahami konsep-konsep yang ada dan mampu menggunakan rumus-rumus matematika untuk menyelesaikan soal-soal fisika (Simanjuntak, 2013). Salah satu materi fisika yang sulit dipelajari oleh siswa adalah materi Hukum Newton (Pohan \& Simamora, 2014; Rosdianto dkk, 2017). Siswa sering merasa jenuh dengan pembelajaran yang berpusat pada guru, karena guru lebih sering menggunakan model konvensional dengan metode ceramah, tanya jawab, dan penugasan sehingga siswa hanya bisa mencatat apa yang didengar dan dijelaskan oleh gurunya, mereka kurang dilibatkan dalam proses menemukan dan mengembangkan pengetahuan sesuai dengan kemampuannya sendiri (Hamdani dkk, 2012). Padahal setiap siswa merupakan subjek dalam proses belajar mengajar yang memiliki karakteristik yang berbeda satu sama lain (Irhamna dkk, 2017; Nadiya dkk, 2016).

Keberhasilan pembelajaran di sekolah dapat dilihat dari hasil belajar siswa dalam prestasi belajarnya (Rahmawati, 2014). Kualitas dan keberhasilan belajar siswa dalam 
prestasi belajar siswa sangat dipengaruhi oleh kemampuan dan ketepatan guru memilih dan menggunakan metode pengajaran (Afcariono, 2008). Pengajaran yang baik adalah upaya yang salah satunya mengembangkan pemahaman yang mendalam terhadap materi dan meningkatkan keterampilan berpikir kritis (Nadiya dkk, 2016). Berdasarkan hasil tes keterampilan berpikir kritis awal yang diberikan, diperoleh data bahwa 22 dari 30 siswa memiliki keterampilan berpikir kritis yang rendah. Selanjutnya peneliti melakukan wawancara dengan guru IPA MTs Makarim Al-akhlak Kota Singkawang perihal rendahnya hasil tes keterampilan berpikir kritis siswa yang rendah. Dari hasil wawancara diperoleh informasi bahwa sebagian besar siswa kurang aktif dalam mengajukan pertanyaan ataupun menyampaikan pendapat saat pembelajaran di kelas, yang berindikasi bahwa keterampilan berpikir kritis mereka masih rendah. Hal ini diperkuat dengan hasil observasi yang dilakukan oleh peneliti selama pembelajaran berlangsung. Ketika guru menyampaikan materi, hanya sedikit siswa yang aktif dalam mengajukan pertanyaan dan menyampaikan pendapat mengenai materi yang diberikan. Dalam proses pembelajaran, guru juga jarang memberikan contoh soal atau permasalahan yang berindikator kemampuan berpikir kritis, sehingga siswa kurang aktif dalam mengajukan pertanyaan dan pendapat mereka.

Keterampilan berpikir kritis sebagai salah satu komponen keterampilan berpikir tingkat tinggi, menggunakan dasar menganalisis argumen dan memunculkan wawasan terhadap tiap-tiap makna dan interpretasi, untuk mengembangkan pola penalaran yang kohesif dan logis (Liliasari, 2003). Keterampilan berpikir kritis merupakan sebuah proses yang digunakan dalam memecahkan masalah, mengambil keputusan, menganalisis, dan melakukan penelitian ilmiah (Johnson, 2009).

Menurut Marzano dkk (1988), terdapat 12 indikator keterampilan berpikir kritis, yaitu: 1 ) focusing on a question (fokus pada pertanyaan), 2) analyzing arguments (menganalisis argumen, 3) asking and answering questions (bertanya dan menjawab pertanyaan), 4) judging the credibility of a source (menilai kredibilitas sumber), 5) observing and judging observation reports (mengamati dan menilai laporan observasi), 6) deducing and judging deductions (menyimpulkan secara deduksi), 7) inducing and judging inductions (menyimpulkan secara induksi), 8) making and judging value judgments (melakukan penilaian), 9) defining terms and judging definitions (mendefinisikan istilah dan melakukan penilaian), 10) identifying assumptions (mengidentifikasi asumsi), 11) deciding on an action (membuat keputusan), dan 12) interacting with others (berinteraksi dengan orang lain).

Salah satu faktor yang mempengaruhi rendahnya keterampilan berpikir kritis siswa adalah proses pembelajaran (Rahayu, 2014). Pembelajaran yang dilakukan guru masih menganut teori tabula John Locke, yang menyatakan bahwa pikiran seorang anak adalah seperti kertas kosong yang putih bersih dan siap menunggu coretan-coretan gurunya (Rosdianto, 2017a). Dengan pembelajaran tersebut siswa bagaikan klise orang dewasa yang pasif dan memerlukan motivasi dari luar (Rosy \& Pahlevi, 2015). Guru mengembangkan kurikulum yang terstruktur dan menentukan bagaimana siswa harus dimotivasi, dirangsang dan dievaluasi sehingga terkesan pembelajaran adalah sekedar pemindahan dan penyerapan pengetahuan sehingga dirasakan kurang bermakna bagi siswa (Maharani, 2013; Rosdianto, 2017b). Dalam mengikuti pembelajaran, siswa cenderung lebih senang mengikuti perintah guru, sehingga membuat siswa cenderung kurang aktif (Sulistri, \& Lisdawati, 2017). Untuk itu diperlukan model pembelajaran yang dapat meningkatkan keterampilan berpikir kritis siswa, salah satunya adalah model generative learning. Hal ini sesuai dengan hasil penelitian yang dilakukan oleh Dewi dkk (2013) dan Uki dkk (2017), bahwa penerapan model Generative Learning memberikan pengaruh terhadap kemampuan berpikir kritis siswa.

Inti dari pembelajaran generatif adalah pikiran manusia aktif mengkonstruksi dan menafsirkan informasi dan selanjutnya menarik kesimpulan berdasarkan informasi tersebut (Osborne \& Wittrock, 1985). Pembelajaran 
generatif melibatkan aktivitas mental berpikir (Ritchie \& Volkl, 2000). Mental berpikir seseorang yang melakukan pembelajaran generatif akan berjalan sejalan proses belajarnya (Flick, 1996).

Tahap-tahap model generative learning (Hamdani dkk, 2012) adalah sebagai berikut:

1. Tahap Orientasi

Siswa diberikan kesempatan untuk membangun kesan mengenai topik yang akan dibahas dengan pengalaman mereka sehari-hari.

2. Tahap Pengungkapan Ide

Siswa diberikan kesempatan mengemukan ide, pada tahap ini siswa menyadari terdapat perbedaan pendapat diantara siswa mengenai pokok bahasan tersebut

3. Tahap Tantangan dan Restrukturisasi Guru menyiapkan suasana dimana siswa meminta membandingkan pendapatnya dengan pendapat siswa lain sehingga terjadi adu argumentasi. Kemudian guru mengusulkan peragaan atau eksperimen untuk menguji kebenaran pendapat mereka

4. Tahap Penerapan

Kegiatan dimana siswa diberi kesempatan untuk menguji ide alternatif untuk membangun pengetahuan baru melalui eksperimen dalam menyelesaikan persoalan yang bervariasi, diharapkan muncul konflik kognitif antara apa yang dimiliki dan apa yang dilihatkan diperagakan. Pada tahap ini diharapkan siswa mulai mengubah struktur pemahaman siswa

5. Tahap Melihat Kembali

Siswa diberi kesempatan untuk mengevaluasi kelemahan dari buku siswa yang lama dan siswa diharapkan memberikan memberikan alasan tentang pengetahuan yang mereka temukan.

Melalui penerapan model generative learning ini diharapkan memberikan pengaruh yang signifikan terhadap peningkatan keterampilan berpikir kritis siswa. Sehingga model ini dapat digunakan sebagai alternatif bagi guru dalam pembelajaran pembelajaran fisika di sekolah.

\section{METODE/EKSPERIMEN}

\section{Jenis dan Desain Penelitian}

Jenis penelitian yang digunakan dalam penelitian ini adalah penelitian kuantitatif. Metode yang digunakan adalah pre experimental design. Desain penelitian ini adalah one group pretest posttest design. Populasi penelitian ini adalah seluruh siswa kelas VIII MTs Makarim Al-akhlak Kota Singkawang. Dikarenakan kelas VIII hanya terdiri atas satu kelas, maka teknik sampling yang digunakan adalah teknik nonprobability sampling berupa sampling jenuh. Sampling jenuh digunakan karena semua anggota populasi digunakan sebagai sampel penelitian (Sugiyono, 2012).

Variabel dalam penelitian ini terdiri dari variabel bebas dan variabel terikat. Variabel bebas dalam penelitian ini adalah penerapan model generative learning, sedangkan variabel terikatnya adalah keterampilan berpikir kritis siswa pada indikator menganalisis, mengamati, menyimpulkan, melakukan penilaian, mendefinisikan istilah, dan mengidentifikasi asumsi. Tes yang digunakan berupa tes uraian sebanyak 10 butir soal untuk mengetahui keterampilan berpikir kritis siswa, di mana siswa diminta untuk memberikan pendapat, melakukan analisis, menarik kesimpulan untuk setiap butir soal yang diberikan. Instrumen pengumpulan data yang digunakan adalah lembar pretest dan posttest. Sebelum tes digunakan dalam penelitian, terlebih dahulu dilakukan uji coba (Arikunto, 2010). Data hasil uji coba instrumen kemudian diolah atau dianalisis.

\section{Teknik Analisis Data}

\section{Uji Normalitas Data}

Untuk pengujian normalitas data, digunakan uji Chi-kuadrat (Sugiyono, 2007) yaitu seperti pada persamaan 1 .

$$
\chi^{2}=\sum_{i=1}^{k} \frac{\left(f_{o}-f_{e}\right)^{2}}{f_{e}}
$$

$f_{0}$ adalah frekuensi observasi dan $f_{e}$ adalah frekuensi harapan. Kriteria pengujian yang digunakan pada $\mathrm{db}=(\mathrm{k}-3)$ dengan taraf signifikansi $\alpha=0,05$ adalah jika $\chi^{2}$ hitung $<\chi^{2}$ tabel, 
maka data dikatakan berasal dari populasi yang berdistribusi normal.

\section{Uji Hipotesis}

Untuk mengetahui seberapa jauh hipotesis yang telah dirumuskan didukung oleh data yang dikumpulkan, maka hipotesis tersebut harus diuji. Jika sebaran data berdistribusi normal, maka data yang diperoleh dianalisis dengan menggunakan uji paired ttest (Sugiyono, 2007) dengan pasangan hipotesis sebagai berikut:

$\mathrm{H}_{\mathrm{o}}$ : Tidak terjadi peningkatan keterampilan berpikir kritis siswa melalui penerapan model generative learning pada materi Hukum Newton

$\mathrm{H}_{\mathrm{a}}$ : Terjadi peningkatan keterampilan berpikir kritis siswa melalui penerapan model generative learning pada materi Hukum Newton.

Rumus yang digunakan adalah:

$$
t_{\text {hitung }}=\frac{X-Y}{\sqrt{\frac{s_{x}^{2}}{n_{x}}+\frac{s_{y}^{2}}{n_{y}}-2 r\left(\frac{s_{x}}{\sqrt{n_{x}}}\right)\left(\frac{s_{y}}{\sqrt{n_{y}}}\right)}}
$$

dengan kriteria pengujian yakni $\mathrm{H}_{0}$ diterima jika thitung $\leq t_{\text {tabel }}$ pada taraf signifikansi $\alpha=0,05$ dan $\mathrm{db}=(\mathrm{n}-1)$ serta untuk harga $\mathrm{t}$ lainnya $\mathrm{H}_{0} \mathrm{di}$ tolak.

Namun, jika sebaran data yang diperoleh tidak normal maka digunakan uji statistik nonparametrik yaitu uji Mc Nemar (Sugiyono, 2001), dengan pasangan hipotesis sebagai berikut:

$\mathrm{H}_{\mathrm{o}}$ : Tidak tejadi peningkatan keterampilan berpikir kritis siswa melalui penerapan model generative learning pada materi Hukum Newton

$\mathrm{Ha}_{\mathrm{a}}$ : Terjadi peningkatan keterampilan berpikir kritis siswa melalui penerapan model generative learning pada materi Hukum Newton.

Rumus yang digunakan adalah:

$$
\chi^{2}=\frac{(|A-D|-1)^{2}}{A+D}
$$

dengan kriteria pengujian yakni $\mathrm{H}_{0}$ diterima jika $\chi^{2}$ hitung $\leq \chi^{2}$ tabel pada taraf signifikansi $\alpha=0,05$ dan $d k=1$ serta untuk harga $x$ lainnya $H_{\circ}$ ditolak.

\section{PEMBAHASAN}

Data yang disajikan dalam penelitian ini adalah data yang diperoleh dari hasil tes berupa pretest dan postest. Data hasil yang diperoleh siswa yang dapat dilihat pada tabel 1 .

Tabel 1. Hasil pretest dan posttest

\begin{tabular}{cccc}
\hline & Pretest & Posttest & Selisih \\
\hline Nilai rata-rata & 43,81 & 65,38 & 16,57 \\
Standar & 5,25 & 6,42 & \\
Deviasi & 53 & 73 & \\
Nilai tertinggi & 55 & 50 & \\
Nilai terendah & 35 & \\
\hline
\end{tabular}

Berdasarkan tabel 1 dapat dilihat bahwa nilai rata-rata hasil posttest sebesar 60,38 lebih tinggi dari hasil pretest sebesar 43,81 . Hal ini menunjukkan bahwa keterampilan berpikir kritis siswa meningkat setelah diberikan perlakuan dengan menggunakan model generative learning. Kemudian nilai pretest dan posttest dianalisis untuk memperoleh kriteria peningkatan keterampilan berpikir kritis siswa setelah diterapkan model generative learning pada materi Hukum Newton dengan menggunakan $\mathrm{N}$-gain (Hake, 1998). Kriteria $\mathrm{N}$ gain untuk peningkatan keterampilan berpikir kritis dapat dilihat pada tabel 2 berikut.

Tabel 2. Kriteria N-gain untuk peningkatan keterampilan berpikir kritis

\begin{tabular}{cc}
\hline Skor N-gain & Kriteria \\
\hline$<g>\geq 0,7$ & Tinggi \\
$0,3 \leq<\mathrm{g}><0,7$ & Sedang \\
$<\mathrm{g}><0,3$ & Rendah \\
\hline
\end{tabular}

Dari analisis $\mathrm{N}$-gain, diperoleh hasil sebagai berikut:

$$
\begin{aligned}
& <g>=\frac{S_{\text {posttest }}-S_{\text {pretest }}}{S_{\text {maks }}-S_{\text {pretest }}} \\
& <g>=\frac{65,38-43,81}{100-43,81} \\
& <g>=\frac{21,57}{56,19} \\
& <g>=0,38
\end{aligned}
$$

Berdasarkan perhitungan di atas, diperoleh bahwa keterampilan berpikir kritis siswa mengalami peningkatan sebesar 0,38 dengan kriteria sedang.

Tahapan selanjutnya adalah menganalisis data dengan menggunakan uji statistik. Langkah pertama adalah melakukan 
uji normalitas data yang bertujuan untuk mengukur apakah data yang dianalisis berdistribusi normal sehingga dapat digunakan dalam statistik parametrik. Rangkuman hasil uji normalitas data pretest dan posttest dapat dilihat pada tabel 3 dan 4 .

Tabel 3. Rangkuman uji normalitas data

\begin{tabular}{ccc}
\multicolumn{3}{c}{ pretest } \\
\hline $\begin{array}{c}\text { Nilai } \chi^{2} \text { hitung } \\
\text { pretest }\end{array}$ & $\begin{array}{c}\text { Nilai } \chi^{2} \text { tabel } \\
\text { pretest }\end{array}$ & Uji Normalitas \\
\hline 7,69 & 5,991 & Tidak Normal \\
\hline
\end{tabular}

Tabel 4. Rangkuman uji normalitas data posttest

\begin{tabular}{ccc}
\hline $\begin{array}{c}\text { Nilai } \chi^{2} \text { hitung } \\
\text { posttest }\end{array}$ & $\begin{array}{c}\text { Nilai } \chi^{2} \text { tabel } \\
\text { posttest }\end{array}$ & Uji Normalitas \\
\hline 0,71 & 5,991 & Normal \\
\hline
\end{tabular}

Dari tabel 2 diperoleh bahwa nilai pretest siswa tidak berdistribusi normal, sedangkan dari tabel 3 diperoleh bahwa nilai posttest siswa berdistribusi normal. Setelah dipastikan bahwa tidak semua data berdistribusi normal, maka uji statistik yang digunakan adalah uji statistik nonparametrik yaitu uji Mc Nemar. Dari hasil perhitungan diperoleh nilai $X^{2}$ hitung $>X^{2}$ tabel yaitu $7,111>3,841$, maka $\mathrm{H}_{\circ}$ ditolak dan $\mathrm{H}_{\mathrm{a}}$ diterima pada taraf signifikansi $\alpha=0,05$.

Dari hasil penelitian menunjukkan bahwa terdapat pengaruh model generative learning terhadap keterampilan berpikir kritis siswa pada materi Hukum Newton di kelas VIII MTs Makarim Al-akhlak Kota Singkawang, dibuktikan dengan perolehan nilai rata-rata pretest siswa sebesar 43,81 dan nilai rata-rata postest sebesar 60,38 . Ini juga dibuktikan dari uji statistik untuk menguji hipotesis penelitian dan diperoleh nilai $X^{2}$ hitung $>X^{2}$ tabel yaitu $7,111>$ 3,841, maka $\mathrm{H}_{0}$ ditolak dan $\mathrm{H}_{\mathrm{a}}$ diterima pada taraf signifikansi $\alpha=0,05$. Hal ini didukung oleh Agnafia dkk (2017), Srianty dkk (2010) dan Sastrini dkk (2014) yang menyatakan bahwa model generative learning memberikan pengaruh yang signifikan terhadap keterampilan berpikir kritis. Hal ini juga diperkuat oleh penelitian yang dilakukan oleh Dewi dkk (2013) dan Nandari (2014) yang menyatakan bahwa penerapan model generative learning efektif dalam meningkatkan keterampilan berpikir kritis.

\section{PENUTUP}

Berdasarkan hasil dan pembahasan yang dilakukan dapat disimpulkan terdapat peningkatan keterampilan berpikir kritis siswa kelas VIII MTs Makarim Al-akhlak Kota Singkawang pada materi Hukum Newton setelah diterapkan model generative learning. Hal ini dapat dilihat dari nilai rata-rata hasil tes keterampilan berpikir kritis siswa sebelum diberi perlakuan (pretest) sebesar 43,81 dan setelah diberi perlakuan (posttest) sebesar 65,38 , yang kemudian dianalisis menggunakan $\mathrm{N}$-gain diperoleh bahwa keterampilan berpikir kritis siswa meningkat sebesar 0,38 dengan kriteris sedang.

Dari uji analisis statistik juga diperoleh bahwa terjadi peningkatan keterampilan berpikir kritis siswa di kelas VIII MTs Makarim Al-akhlak Kota Singkawang setelah diterapkan model generative learning pada materi hukum Newton. Hal ini dapat dilihat dari uji hipotesis di mana nilai $X^{2}$ hitung $>X^{2}$ tabel yaitu $7,111>3,841$ dengan taraf signifikansi sebesar $5 \%$.

\section{DAFTAR PUSTAKA}

Afcariono, M. (2008). Penerapan pembelajaran berbasis masalah untuk meningkatkan kemampuan berpikir siswa pada mata pelajaran biologi. Jurnal Pendidikan Inovatif, 3(2), 65-68.

Agnafia, D. N., Sutarno, S., \& Prayitno, B. A. (2017). Pengembangan Modul Berbasis Generative Learning Pada Materi Keanekaragaman Hayati Untuk Meningkatkan Kemampuan Berpikir Kritis Siswa SMA Negeri 1 Kedunggalar Ngawi. INKUIRI Jurnal Pendidikan IPA, 6(2), 67-82.

Arikunto, S. (2010). Dasar-dasar Evaluasi Pendidikan. Jakarta: Bumi Aksara.

Dewi, K. A. P., Sulastri, M., \& Agustiana, I. G. T. (2013). Pengaruh Model Pembelajaran Generatif Terhadap Kemampuan Berpikir Kritis IPA Siswa Kelas V Di Gugus VIII Kecamatan Buleleng. MIMBAR PGSD, 1.

Flick, L. B. (1996). Understanding a generative learning model of instruction: A case study of elementary teacher planning. Journal of 
Science Teacher Education, 7(2), 95-122. https://doi.org/10.1007/BF00114121

Hake, R. R. (1998). Interactive-engagement vs Traditional Methods: A Six-thousandstudent Survey of Mechanics Test Data For Introductory Physics Courses. Department of Physics, Indiana University, Bloomington, Indiana 47405.

Hamdani, D., Eva, K., \& Indra, S. (2012). Pengaruh Model Pembelajaran Generatif Dengan Menggunakan Alat Peraga Terhadap Pemahaman Konsep Cahaya Kelas VIII Di SMP Negeri 7 Kota Bengkulu. EXACTA, 10(1), 79-88.

Irhamna, I., Rosdianto, H., \& Murdani, E. (2017). Penerapan Model Learning Cycle 5E untuk Meningkatkan Keterampilan Berpikir Kritis Siswa Pada Materi Fluida Statis Kelas VIII. Jurnal Fisika FLUX, 14(1), 61-64. http://dx.doi.org/10.20527/flux.v14i1.3839

Johnson, E. B. (2009). Contextual Teaching and Learning. Bandung: Mizan Learning Centre (MLC).

Liliasari. (2003). Peningkatan Mutu Guru dalam Keterampilan Bepikir Tingkat Tinggi Melalui Model Pembelajaran Kapita Selekta Kimia Sekolah Lanjutan. Jurnal Pendidikan Matematika dan Sains, 8(3).

Marzano, R. J. (1988). Dimensions of thinking: $A$ framework for curriculum and instruction. The Association for Supervision and Curriculum Development, $125 \mathrm{~N}$. West St., Alexandria, VA 22314-2798.

Maharani, D. F. I., (2013). Penerapan Model Pembelajaran Better Teaching And Learning Materi Gerak Lurus Untuk Mengembangkan Kemampuan Berpikir Kritis Dan Karakter Siswa Kelas VII SMP. (Skripsi, Program studi pendidikan Fisika Universitas Negeri Semarang, Semarang).

Nadiya, Rosdianto, H., \& Murdani, E. (2016). Penerapan Model Pembelajaran Group Investigation (Gl) untuk Meningkatkan Keterampilan Berpikir Kritis Siswa pada Materi Gerak Lurus Kelas X. JIPF (Jurnal IImu Pendidikan Fisika), 1(2), 49-51. http://dx.doi.org/10.26737/iipf.v112.63
Nandari, E. M. (2014). Pengaruh Model Pembelajaran Generatif terhadap Keterampilan Berpikir Kritis Fisika Siswa Kelas $X$ di SMA Negeri 7 Malang. SKRIPSI Jurusan Fisika-Fakultas MIPA UM.

Osborne, R., \& Wittrock, M. (1985). The Generative Learning Model and its Implications for Science Education. Studies in Science Education, 12(1), 59-87. https://doi.org/10.1080/0305726850855992 $\underline{3}$

Pohan, D., \& Simamora, P. (2014). Pengaruh Model Pembelajaran Kooperatif Tipe Jigsaw Berbasis Macromedia Flash Terhadap Hasil Belajar Siswa Pada Materi Pokok Hukum-hukum Newton. INPAFI (Inovasi Pembelajaran Fisika), 2(3), 45-53.

Ritchie, D., \& Volkl, C. (2000). Effectiveness of Two Generative Learning Strategies in the Science Classroom. School Science and Mathematics, 100(2), 83-89. https://doi.org/10.1111/j.19498594.2000.tb17240.x

Rahayu, E.P. (2014). Peningkatan Kemampuan Berpikir Kritis Matematis Melalui Model Pembelajaran Kooperatif Tipe Group Investigation Siswa Kelas IV SD Negeri Suka Maju 3 Depok. Skripsi, Program Studi Pendidikan Guru Madrasah Ibtidaiyah. Universitas Islam Negeri Syarif Didayatullah: Jakarta.

Rahmawati, M. D. (2014). Analisis Keterampilan Berpikir Kritis Siswa pada Pembelajaran Fisika dengan Pendekatan Starter Eksperimen. RADIASI: Jurnal Berkala Pendidikan Fisika, 5(1), 73-76.

Rosdianto, H. (2017a). Pengaruh Model Generative Learning Terhadap Hasil Belajar Ranah Kognitif Siswa Pada Materi Hukum Newton. Jurnal Pendidikan Fisika Dan Keilmuan (JPFK), 3(2), 66-69. https://doi.org/10.25273/ipfk.v3i2.1288

Rosdianto, H. (2017b). Students` Conceptual Understanding through Generative Learning Model in Topic "Light". JPI (Jurnal Pendidikan Indonesia), 6(2), 259-262

Rosdianto, H., Murdani, E., \& Hendra. (2017). The Implementation of POE (Predict Observe Explain) Model to Improve Student's Concept Understanding on Newton's Law. 
Jurnal Pendidikan Fisika, 6(1), 55-57. https://doi.org/10.22611/jpf.v6i1.6899

Rosy, B., \& Pahlevi, T. (2015). Penerapan Problem Based Learning Untuk Meningkatkan Kemampuan Berpikir Kritis dan Keterampilan Memecahkan Masalah. In Prosiding Seminar Nasional Pendidikan Ekonomi FE UNY" Profesionalisme Pendidik dalam Dinamika Kurikulum Pendidikan di Indonesia pada Era MEA". Fakultas Ekonomi UNY.

Sastrini, M., Garminah, N. N., Hum, M., \& Wibawa, I. M. C. (2014). Pengaruh Model Pembelajaran Generatif Terhadap Keterampilan Berpikir Kritis IPA Siswa SD Kelas V Gugus III Kecamatan Tejakula. MIMBAR PGSD, 2(1).

Simanjuntak, M. P. (2013). Implementasi Model Pembelajaran Kooperatif Tipe NHT Terhadap Hasil Belajar Siswa SMP Pada Materi Gaya dan Hukum Newton T.P 2012/2013. Jurnal INPAFI, 1(2), 107-113.

Srianty, S., Samad, A., \& Patandean, A. J. (2010). Upaya Meningkatkan Kemampuan Berpikir Kritis Fisika Siswa Kelas XI IPA3 SMA Negeri 1 Bungoro Melalui Model Pembelajaran Generatif. Jurnal Sains dan Pendidikan Fisika, 7(1), 1-12.

Sugiyono. (2007). Statistika Untuk Penelitian. Bandung: Alfabeta.

Sugiyono. (2001). Statistik Nonparametris Untuk Penelitian. Bandung: Alfabeta.

Sugiyono. (2012). Metode Penelitian Kuantitatif, Kualitatif dan $R \& D$. Bandung: Alfabeta.

Sulistri, E., \& Lisdawati, L. (2017). Using Three-Tier Test to Identify the Quantity of Student that Having Misconception on Newton's Laws of Motion Concept. JIPF (Jurnal IImu Pendidikan Fisika), 2(1), 4-6. http://dx.doi.org/10.26737/jipf.v2i1.195

Uki, R. S., Saehana, S., \& Pasaribu, M. (2017). Pengaruh Model Pembelajaran Generatif Berbasis Hands-on activity pada Materi Fluida Dinamis terhadap Kemampuan Berpikir Kritis Siswa. Physics Communication, 1(2), 6-11. 